\title{
What's the point of parenthood? The agreed parenthood provisions under the HFE Act 2008 and inconsistency with intention
}

Article

Accepted Version

Callus, T. (2019) What's the point of parenthood? The agreed parenthood provisions under the HFE Act 2008 and inconsistency with intention. Journal of Social Welfare and Family Law, 41 (4). pp. 389-405. ISSN 1469-9621 doi: https://doi.org/10.1080/09649069.2019.1663002 Available at https://centaur.reading.ac.uk/82620/

It is advisable to refer to the publisher's version if you intend to cite from the work. See Guidance on citing.

To link to this article DOI: http://dx.doi.org/10.1080/09649069.2019.1663002

Publisher: Routledge

All outputs in CentAUR are protected by Intellectual Property Rights law, including copyright law. Copyright and IPR is retained by the creators or other copyright holders. Terms and conditions for use of this material are defined in the End User Agreement. 


\section{CentAUR}

Central Archive at the University of Reading

Reading's research outputs online 


\section{What's the point of parenthood? The agreed parenthood provisions under the HFE Act 2008 and inconsistency with intention.}

Thérèse Callus, School of Law, University of Reading, UK ${ }^{1}$

Through an analysis of cases where a declaration of non-parentage has been made in the context of flawed consent to the agreed parenthood provisions under the HFE Act 2008, this article illustrates the inconsistencies of the current law relating to intention as the basis for agreed parenthood. I argue that the courts are not always faithful to the underlying policy of recognising intention to attribute legal parenthood, in particular where the putative parents' relationship has broken down. If intention, expressed through consent to the use of donated gametes and ensuing parenthood, is to provide as much certainty as parentage based upon a genetic link, then administrative flaws in the respect of the legislative formalities should not allow parenthood to be challenged where there is nevertheless evidence of the parties' intention to become parents. I argue that it is problematic to prioritise certainty of the existing inadequate procedural conditions at the expense of certainty for the child's identity. Given that parenthood is central to an individual's identity and consequently has repercussions not only for the individuals concerned, but for wider society too, a much clearer articulation of how intention is enshrined as the basis of parenthood is needed.

\section{Parenthood - intention - non-parentage - HFE Act 2008 - genealogical justice}

Writing over ten years ago, Andrew Bainham asked 'what is the point of birth registration?'(Bainham, 2008). ${ }^{1}$ This question may have been the precursor to the question I pose in this paper: what is the point of legally recognised parenthood? It is no longer rooted in the formal identification of a biological progenitor: first the extension by adoption, then the use of donated gametes, and subsequent recognition of same-sex agreed parents under the Human Fertilisation \& Embryology Act 2008 (hereafter HFE Act 2008) negate such a basis. If we believe its purpose is to give legal status to a functional parent - one who nurtures and cares for a child on a permanent basis - then we may find that we are dissatisfied here too. A number of functional parents do not enjoy a formally recognised parental status: either because they fail to have recourse to legal mechanisms such as the attribution of parental

\footnotetext{
${ }^{1}$ m.t.callus@reading.ac.uk
} 
responsibility for a step-parent (s4A Children Act 1989), or a parental order following a surrogacy arrangement (s54 HFE Act 2008), or because they were misled into thinking that they benefitted from legal provisions granting them parenthood under the HFE Act 2008, when in fact they do not. It is the latter group which is the focus of this paper as it highlights a need for the law to further develop and refine how intention can be better enshrined as the basis upon which parenthood is legally recognised. It is of particular importance in relation to a growing number of same-sex couples who have children: the latest figures and trends published by the HFEA indicate that more female patients are accessing licensed ART treatment with a female partner, and thus are relying on the agreed parenthood consent conditions adopted in the reform of 2008 (HFEA 2014a).

A number of cases have revealed flaws in the procedure for establishing parenthood under the HFE Act 2008, requiring a declaration of parentage, or in some cases non-parentage.

Although relatively few, the cases highlight a need for greater certainty and consistency than exists at present in the basis of the agreed parenthood provisions under the 2008 Act. They also raise the critical issue of how the underlying policy of enshrining intention as the basis for parental status is effected. It is clear that the attribution of legal parenthood and its consequences pose important questions for us as individuals and for society. Indeed, as Munby $\mathrm{P}$ has noted in the case of Re HFEA (Cases A, B,C, D, E, F and G) [2015] EWHC 2602 Fam:

'Legal parenthood is 'a question of most fundamental gravity and importance. What, after all, to any child, to any parent, never mind to future generations and, indeed, to society at large, can be more important, emotionally, psychologically, socially and legally, than the answer to the question: who is my parent? Is this my child?" [3]. 
In this article, I argue that the basis of the procedure for recognising parenthood under the Act needs to be more clearly articulated and that this is indicative of a wider concern on the need to revisit more generally the model of legal parenthood, including how multiple parents might be recognised and identified as explored elsewhere (Jackson 2006; Diduck 2007; Callus 2012; Smith 2013; Cammu 2018). I identify some of the shortcomings inherent in the current consent procedure for establishing intention under the agreed parenthood provisions, especially when the intended parties no longer agree on what were their respective intentions. It is striking that where the parents are a heterosexual couple, the courts seem to be willing to 'read down' the strict formal requirements of the consent process, which is not the case where the parties are a same-sex couple whose relationship has broken down. The inconsistencies with how the current consent procedure enshrines intention are explored in Part I. In Part II, I claim that both the legislation and the ensuing case law fail to acknowledge the crucial identity-forming component of parenthood for children born using donated gametes - which is ultimately a question of 'genealogical justice' (Legendre 1992). Consequently, I suggest that the use of the declaration of non-parentage in some of the cases is misplaced and that it has serious connotations for the interests of the children concerned. Where children are being brought up by those they believe to be their parents, and where there is evidence of the adults' intention to be a legal parent (albeit erroneously recorded) prioritising certainty of the existing inadequate procedural conditions at the expense of certainty for the children's identity, is problematic. This is because it fails to respect the underlying policy inherent in the 2008 Act of using intention as the basis for parenthood. Furthermore, the current position is not consistent insofar as it varies according to whether the (parent) parties are still in agreement or not. Consequently, the argument is made that the purpose of legal agreed parenthood with intention as its basis needs to be better articulated. 


\section{The chaos of consent in the agreed parenthood provisions}

Given that parenthood is central to an individual's identity, certainty and permanence are two of the law's goals in this regard (Callus 2012; Smith 2013). Yet, in the context of donated gametes in assisted reproductive technologies (ART) where formal statutory requirements of consent to the use of donor gametes confer parental status through agreement under the Human Fertilisation \& Embryology Act 2008, certainty is not always assured for the children or parents. According to an audit carried out by the Human Fertilisation \& Embryology Authority (hereafter HFEA), there were 'numerous cases' where the legal status of parenthood was in doubt across 'many clinics' in which ART had been used (HFEA, 2016). The audit further revealed that this was largely the result of 'repeated human error' (HFEA 2016). In 2017, the Authority's Report on the State of the Fertility Sector noted that one of the areas where there is most non-compliance with the provision of the Act, is that concerning consent and consequently, parenthood (HFEA 2017 p17-18). Previously, the HFEA had also reported on 'widespread instances of poor practice' in the recording of consent and the parenthood conditions (HFEA 2014b). This means that someone who thought they had agreed to become a parent may find that the flaw negates their legal status; or conversely, that someone becomes a legal parent unknowingly if fraudulent use of their consent is made. ${ }^{2}$

Testament to the inadequacies of the consent provisions in the HFE Act 2008 insofar as they focus on a procedure which is vulnerable to administrative errors by the clinic applying them, is the increasing number of cases concerning confirmation or denial of parental status for a child following assisted conception. ${ }^{3}$ On the one hand, the case law, predominantly under the guidance of the President of the Family Division, has taken a pragmatic stance with respect to administrative errors caused by the incorrect recording of consent by clinics, and in many cases, evidence of the intention to be a parent has been accepted notwithstanding the 
administrative errors. This pragmatic approach has now been endorsed in a string of judgments in which the President of the Family Division has set out standard form procedure for such cases: In the Matter of the Human Fertilisation and Embryology Act 2008 (Cases AD, $A E, A F, A G$ and $A H$ ) (No 2) [2017] EWHC 1782 (Fam). Declarations of parentage have thus been made where despite lack of adherence to the strict formalities of obtaining consent, there is agreement by all the parties that their intention was to become legal parents and that they believed they were subject to the provisions of the Act to this effect. ${ }^{4}$ In some cases, it is held to be 'more likely than not' that the mother's partner intended or did indeed sign the relevant paperwork ( $X v Y v$ St Barts [2015] EWFC 13 at [15]). In others, it has been found as a matter of 'content and construction' that the consent albeit given in the wrong forms, should be recognised (Re I (HFE Act 2008) [2016] EWHC 791 (Fam)). Nevertheless, the cases have raised serious questions as to consequences of having to interpret the parties' intentions when the formal consent requirements have been flouted. Where there is no conflict or dispute between the parents, then the principal issue is that of the stress, worry, uncertainty and intrusion into their privacy that the parents have to suffer in order to have their legal status confirmed. It is invariably held to be in the child's best interests that the parenthood of the functional parents be formally confirmed. However, this is as a consequence of 'reading down' the strict statutory provisions on consent formalities. Consequently, the desirable certainty for the families is achieved, but at the price of certainty in how strictly the legislative procedural requirements will be applied in any given case. This is evident in cases where parents no longer agree on their intention at the time of the conception, because some cases have prioritised a strict application of the statutory formalities to deny parental status. This places the children in a very vulnerable position and distinguishes them from genetically linked children, who, irrespective of the parents' conflict, will be able to rely upon genetics to maintain the parent's legal status. 
Two cases in particular are worth examining. In one case, parenthood of the second female parent is at the mercy of the birth mother despite the court acknowledging the importance of the second parent for the child, and, indeed, evidence of intention to be a parent; in another, denial of parenthood of the second parent was chosen by the parties in the name of equality between children born under two different regimes, following the breakdown of their relationship.

\section{Re E and F: when form triumphs over function}

The first case, Re E and F (Assisted reproduction: parent) [2013] EWHC 1418 (Fam) gave priority to upholding the strict formal regime implemented by the 2008 Act to deny the parenthood of the second female parent, despite the fact that the evidence suggested that at the time of the treatment both she and the intended mother who would carry the baby, believed that they had consented to the parenthood of the mother's partner. This interpretation was supported by the fact that both parents were named on the child's birth certificate. The judge also held that 'taking their evidence overall, they both acknowledged that they wished AB to have legal parental status...' (para 37). Furthermore, the birth mother's evidence included a blog she had written in which the judge found 'she gave reasons for why the couple had waited for the third round of treatment - because work had been busy, because she wanted to have the right positive mental attitude, and finally to take advantage of the new law' (emphasis added para 42). The judge later goes on to state:

'Consistent with her general intention that $\mathrm{AB}$ should acquire the legal status of 'parent', CD told me that she had followed the website links suggested by her 'Fertility Forum' correspondent, and in the period before the third treatment, she downloaded 
the requisite forms from the internet so as to give effect to their joint intention to confer parentage in accordance with the new law. CD explained that in doing so she felt that this "would give her some parental responsibility, I thought. She would then feel included and step up to the mark...".[44\}

The couple signed the WP and PP forms (again, it was emphasised "to ensure AB also had legal parentage for any children born as a result of this treatment" - per CD), and handed them to the nurse at the clinic.'[45](original emphasis).

When the parties' relationship broke down, the birth mother relied upon the procedural irregularities to claim that her partner should not be declared the other parent and that the birth certificate should be amended to remove her name from it. Underlining the procedural requirements, Cobb J held that they had not been respected, either in their temporal aspects or in their substance. He therefore held that the parties had not intended the second female parent provisions to apply and duly made a declaration of non-parentage. Furthermore, he held that, because it was probable that the parenthood forms has been signed after the final insemination and without the requisite counselling, the licence conditions had been flouted and consequently, the treatment provided was not under licence so that the provisions of the HFE Act could not apply (at para 70). He underlined the need for certainty under the law and respect for the formal requirements, stating that he:

'must respect the carefully crafted legislative scheme which provides statutory authority for regulating assisted reproduction. As Hale LJ said in Centre for Reproductive Medicine v $U$ [2002] EWCA Civ 565 at $\$ 24[\ldots] " C e n t r e s$, the HFEA and the courts have to respect that scheme, however great their sympathy for the plight of particular individuals caught up in it." If there is any public policy 
argument engaged here, it points in favour of upholding the tightly regulated regime of assisted reproduction, not relaxing it.' (per Cobb J para 94-95).

However, in contrast, in cases where the parents are in agreement, as noted above, the court has underlined the fact that it is 'more likely than not' that the mother's partner had signed the forms ( $X \& Y v$ St Bartholomew's Hospital Centre (Assisted reproduction: parent) [2015] EWFC 13). In $X \& Y$, the judge held that although the requisite forms were not on file, it was likely that they had been signed and respected the legal procedural requirements and that it was the Clinic which had mislaid them. Theis J therefore found that there had not been a violation of the licence conditions and that the treatment provided was covered under the 2008 Act. Yet this is in stark contrast to the finding in $\operatorname{Re} E \& F$ that a violation of the legislative procedure vitiated the licence under which the clinic operates and as a result, the parenthood provisions could not be applied. Crucially, in $X \& Y$, both parents in the heterosexual couple were in agreement as to their intention. But we may well ask whether the fact that the parents are in agreement should be the decisive factor. Although there are some slight factual differences between the two cases in the timing of the alleged signing of the paperwork, there is nothing substantial to support the finding in $X \& Y$ that the clinic mislaid the forms, compared to the finding in $\operatorname{Re} E \& F$ that although forms had been signed, it was likely they had been signed too late. Both cases recognise the apparent intention of the parties at the time of the treatment for the mothers' partners to be recognised as parents. Thus, if intention is intended to replace the certainty of the genetic link, that intention must be the one at the time of the treatment if we are to ensure maximum certainty. The issue therefore is one of how that intention can be robustly recorded. 
Further, in $\operatorname{Re} E \& F$, Cobb J's presentation of the evidence could be relied upon to give greater support to the question of public policy which the non-birth parent raised as a reason not to make the declaration of non-parentage. Indeed, there may be greater force in the need to uphold the policy behind the 2008 Act of enshrining intention, compared to the need to interpret strictly the formal requirements of consent provision. Despite the 'certainty' of the application of the law that the latter approach may give, it ignores the fact that, given the confusion the clinics themselves seemed to display in the adoption of the new consent forms following the Act, it seems inequitable to deny parentage, which on the evidence stated by the judge seemed to indicate the intention of both adults for the non-birth partner to be a legal parent. Moreover, ignoring this public policy consideration negates the importance of the psychological parent and the accepted judicial recognition of the different elements that parenthood can involve, including genetic, gestation, social and psychological parenthood, as articulated by Hale LJ in $\operatorname{Re} G$ (children) [2006] UKHL 43 (at paras 33-35). Indeed, in $R e E$ and $F$, the judge did note that for the child, the mother's partner was her parent at the time of the birth and for the remaining duration of the adults' relationship, and consequently that leave should be given for the non-legal parent to apply for a child arrangements order to confirm the practical and emotional input that this person could have in the life of the child. But the consequence of the non-declaration of parentage is that for legal purposes, although a functional 'parent', the child would not automatically be treated as a dependent for succession purposes, nor benefit from any legal status with this parent's family. The bright line interpretation of consent provision in this case despite the finding of evidence of intention at the time of the conception, denies the child's legal status as a child of a person who clearly has carried out, and intended to continue with, a parental role. The court indicated that child arrangement orders under section 8 Children Act 1989 would be the option available to the parent to acquire legal status vis-à-vis the child, but this would not 
extend to recognising parental identity. As a consequence, this child will lose one half of his legal family, which will affect his sense of identity and belonging. Crucially, as lamented by Munby $\mathrm{J}$ in the subsequent case of $R e L$, the child was not legally represented in this case. We may wonder whether further argument on the rights and interests of the child would have justified a different outcome.

\section{Re L-against the policy of the 2008 Act?}

The second case to consider is that of Re L [2016] EWHC 2266 (Fam), where a couple sought a declaration of non-parentage of the mother's partner, despite the fact that both had signed the birth certificate and had signed some forms which would suggest that they believed that the partner would fall within the second female parent provisions. Munby P found that:

'From the outset of that treatment, it was the intention of both $\mathrm{X}$ and $\mathrm{Y}$ that $\mathrm{Y}$ would be a legal parent of $\mathrm{C} 2$. Each was aware that this was a matter which, legally, required the signing by each of them of consent forms. Each of them believed that they had signed the relevant forms as legally required and, more generally, had done whatever was needed to ensure that they would both be parents. iii) From the moment when the pregnancy was confirmed, both $\mathrm{X}$ and $\mathrm{Y}$ believed that $\mathrm{Y}$ was the other parent of the child. That remained their belief when C2 was born' [9].

In this case, the couple had had a first child before the 2008 Act came into force and they then argued that following their relationship breakdown, they did not want the children to be treated differently, with the second one having two parents because she was conceived after the 2008 Act came into force. They both agreed that a declaration of non-parentage should be made. The judge proceeded to make the requested declaration and ordered that the birth 
certificate be amended on the basis that there was a clear deficiency in the correct paperwork to comply with the formal requirements of the Act,

One striking element is that although the child was independently represented by the Guardian, the Guardian notes that 'The Declaration sought is far more about the parental relationship and is not a comment on the parent-child relationship'.[19] This surely denies the core of legal parental status as being one of identity for the child. The Guardian goes on to find that the welfare of the child would not be harmed by making the declaration sought (or achieving the same end via different means if less intrusive) as it ensured equality between the two half-siblings and did not impact upon the functional reality of the shared care of the children between the two adults. The Guardian's assertion (and its apparent acceptance by the judge) is all the more surprising given that it is accepted that children should not be treated differently simply because of the status of their parents' relationship status. Whilst it may not impact upon the functional reality, there is both symbolic and practical relevance to parental status which appear to have been side-lined.

Furthermore, beyond the particular individual circumstances of this case, there is a question of policy: if a legislative model relies on intention, then a formal irregularity or disagreement between the parties involved, should not be used to deny the legal effect of that intention. One of the criticisms of the law before the 2008 reform was that there was no legal recognition of intention to enable a mother's partner for example, to be a legal parent, despite the fact that she was clearly a parent to the child (Re D (Contact and PR: Lesbian Mothers and Known Father) (No 2) [2006] EWHC 2 (Fam)). Given that the reform sought to concretise intention as the legal mechanism to convey parenthood, it seems erroneous to ignore the clear intention as evidenced at the time of conception because the parties' relationship has broken down. Moreover, as noted above, where the parties are not in conflict, 
the judges have not shied away from giving effect to the flawed consent. The existence of conflict between the parents should not be decisive in the recognition of parenthood. After all, if one biological parent separates from the other, this can have no effect on their legal parental status and the courts are keen to ensure that the relationship with the other parent is preserved. If society and the law are serious in recognising that other types of parental relationships deserve equal recognition with genetic parents, then the same emphasis should be placed on keeping the relationship alive between the parent who intended to be a parent at the time of conception, despite the breakdown of the relationship between her and the birth mother. Once again, this brings into relief the incoherence between the apparent policy and purpose of the 2008 reforms and the strict application of the consent requirements.

What these cases concerning procedural irregularities also show is that when such an important legal status is at stake, the appropriateness of the procedure itself must be questioned. As Munby J himself stated in The matter of the Human Fertilisation and Embryology Act 2008 (Cases A, B, C, D, E, F, G and H) [2015] EWHC 2602 (Fam), given the gravity of the issue of the attribution of parental status, it should be seen as just as important as other legal transactions, for example regarding property, which invite formal consideration and meticulous execution (para 111). We might also question how appropriate the procedure is for enshrining intention, if when faced with the wrong form being completed, a couple or individual may reject their status because their circumstances have changed. Or indeed, that previously given consent is fraudulently relied upon after a couple have separated which imposes parenthood on an unknowing ex-partner, as in ARB $v I V F$ Hammersmith Ltd [2017] EWHC 2438 (QB). This contrasts starkly with the position following sexual procreation where once the embryo has been conceived and the child subsequently born, a genetic parent cannot reject his or her parenthood merely because the intentions or circumstances have changed. We may well ask why we should be content with a 
statutory interpretation which allows such uncertainty just because the child has been conceived in vitro and donor gametes may have been used. If it may be easier to support a strict bright-line interpretation of consent prior to implantation, it is much more difficult, and in my opinion, inappropriate, to adopt such an approach when the child exists and is living as a child of a couple. It is possible to suggest that, despite errors in the recording of consent, one member of a couple should be estopped from claiming that the intention had not been to become a parent, just because the adults' relationship has broken down and a flaw in the procedure has been identified.

The procedural inadequacies in the 2008 Act therefore deny both a consistent strict application of the consent requirements, and certainty for children born within the framework of the agreed parenthood provisions. It is this lack of certainty which poses a more fundamental question relating to an individual's identity and what we might term 'genealogical justice'. My argument is that the inconsistencies in the procedure provided for in the agreed parenthood provisions require us to consider more fully the purpose of legal parenthood.

\section{Why we need greater consistency and certainty: parenthood as an element of 'genealogical justice'}

The cases referred to above in the context of declarations of parentage and non-parentage, testify to the inadequacy of the attempts to reconceptualise parenthood in the light of assisted conception techniques and various family forms. In 'natural' conception, genetic certainty provides the basis for legal parenthood. Given that the purpose of the HFE Act 2008 was to enshrine intention as the equivalent to a genetic link, allowing administrative errors in the recording of that consent to deny the legal parenthood because the parents' relationship has 
broken down, denies children in these situations a minimum level of certainty. Using declarations of non-parentage in this latter context thus undermines the very purpose of the legislative parenthood provisions which have enshrined intention, evidenced by consent, as the means by which legal parenthood is attributed. In the context of ART, a declaration of non-parentage effectively denies a child the opportunity of having another legal parent, even though they may maintain an effective emotional relationship with someone who carries out a parenting role. ${ }^{5}$

Indeed, all of the cases concern children who have a relationship and family identity with the adults who believed themselves to be parents. Yet, even in those cases where the children were separately represented (as Munby $\mathrm{J}$ indicated they should be where conflict exists), the emphasis appears to be on respect for the inadequate procedural requirements rather than a purposive interpretation of what is necessary in the interests of the child in having those she believes to be her parents, legally recognised. As noted above, in $\operatorname{Re} L$, the guardian preferred to qualify the case as one concerning the parental relationship and not the parent-child relationship. Whilst this may be accurate in terms of the functional parenting role which the non-birth parent would continue to play, it seems to ignore the very crucial identity-forming element which legal parenthood implies for the child. Further, it minimises the psychological importance for the child to know that the person with whom she has a parental relationship is indeed recognised as such formally - for example, for the purposes of consenting to medical treatment, or being contacted by the child's school, or even for the child not to feel different to others (Campbell, 2007). Moreover, in $R e L$, the welfare of the child who was the subject of the proceedings was collated with the welfare of her half sibling insofar as it was noted that it would be important for the two children to have the same status. Once again, this seems to ignore the central policy behind the 2008 Act in ensuring more children benefit 
from having their functional parent recognised as their legal parent. Fundamentally, given that identity is 'an organizing framework which holds the past and present together providing some anticipated shape to future life', (Masson and Harrison (1994)), it is crucial to recognise that parenting is as much about the child-parent relationship as the parent-child relationship (Brannen and O’Brian (1996)).

\section{The importance of identity requires certainty - for the individual}

Consenting to become a parent essentially includes agreeing for another individual's identity to be inextricably bound to your own. As Munby $\mathrm{J}$ underlined, recognising the legal parents (in the context of surrogacy through a parental order under s54 HFE Act 2008):

'goes to the most fundamental aspects of status and, transcending even status, to the very identity of the child as a human being: who he is and who his parents are. It is central to his being, whether as an individual or as a member of his family'. ( $\operatorname{Re} X(A$ Child) (Surrogacy: Time Limit) [2014] EWHC 3135 (Fam), [2015] Fam 186, at [59]).

Further support for the importance of identity can be found in the growing awareness of the need for children to know and feel a part of a wider family group. A case concerning contact between a known donor's parents and a child born to legal parents in a same-sex couple supports this (Re G (A child) [2018] EWCA Civ 305). In this case, the Court of Appeal upheld a contact order in favour of a known donor to include contact with the donor's parents - the child's biological grand-parents. According to the unanimous Court, such contact was necessary to give the child 'a greater sense of and understanding of his paternal lineage' (at

para 16). With greater use of donated gametes, this familial lineage must also include de facto functional parents and relatives, as well as those who are genetically linked. The importance of identity and belonging is also inherent in the jurisprudence of the European Court of Human Rights. An individual's identity is bound up with their legal parent: acquisition of 
nationality is inextricably linked; and domestic recognition of prohibited degrees of relationship translate social and cultural expectations of accepted behaviour and relationships. Article 8 of the ECHR guarantees respect for such elements of an individual's private and family life which define personal identity, as established amongst others in Marckx v Belgium ((1979) Application no. 6833/74 (1979) 2 EHRR 330) and Johnston v Ireland ((1986) EHRR 203). Likewise, the United Nations Convention on the Rights of the Child asserts in its own article 8 that a child has a right 'to preserve his or her identity... and family relations'. The central importance of identity in the specific context of surrogacy as outlined by Mulligan (2018) extends to all children born using donated gametes.

Ultimately, donor-conceived children need to be provided with the potential for the same long term certainty (albeit imperfect) as those born to biological parents with respect to the permanence of their legal parents. Indeed, it has been accepted since the abolition of the distinction legitimate/illegitimate in the Family Law Reform Act 1987, that children should not be discriminated against on the basis of their parents' relationship. This is also relevant in respect of the provisions of the 2008 Act which differentiate between potential parents according to either the marital status of the parties, or for the second female parent, whether she is in a Civil Partnership with the birth mother. If they are married, or in a civil partnership, then parenthood is conferred by the consent to the implantation of the embryo, gametes or IVF, unless it is shown that no such consent was given (HFE Act 2008, S 35(1) for heterosexual married couples; s 42(1) for same sex married or civil partnered couples). However, if the couple are not in a formally recognised union and are using the agreed parenthood provisions, the carrying mother has to have treatment at a licensed clinic and both the mother and the intended parent must consent to the agreed parent acquiring legal parenthood status (HFE Act 2008, s.36, 37 for heterosexual couples; s 43, 44 for same-sex 
couples). This added administrative complexity makes the clinical team's job potentially more difficult and vulnerable to error.

Likewise, discrimination between children cannot be justified by reference to the mode of conception. Although any parental relationship has the potential to fall victim to a revelation that it is not a legally recognised parenthood, the risks inherent in the current consent procedure and reliance upon a continued good relationship between the adult parents are far greater than in a 'natural' procreation scenario. This is because in the latter case, the genetic link and ensuing legal status will survive any relationship breakdown; if consent to donor insemination is deemed invalid, the child loses one half of her legal family, and accompanying benefits. Clearly, irrespective of the mode of conception (that is whether it is by sexual intercourse or ART), there will always be instances where an individual may

believe $\mathrm{s} / \mathrm{he}$ is a legal parent when in fact $\mathrm{s} / \mathrm{he}$ is not. The provision in s55A Family Law Act 1986 of a declaration of parentage (and a contrario non-parentage) bears witness to this possibility. Yet, in the context of 'natural' procreation (as opposed to ART) such a declaration does not close the door to the potential identification of the genetic parent to the child, who will, by default, be the legal parent. The introduction of s55A was clearly motivated by the desire to recognise genetic parentage and the legal certainty that provides, both for the individual and for society.

\section{The importance of identity requires certainty - for society}

Parenthood is a social institution which provides a structured and durable mechanism to ensure that each individual is attached to another, in order to provide a certain 'social continuity' (Epstein, 1992). The French anthropologist, Pierre Legendre, paraphrasing the Roman civil law notion of vitam instituere, has acknowledged that 'it is not enough to produce human flesh; we need to ensure that the person created has a status within a 
recognised social institution' (Legendre, 1985). The certainty that this implies is in effect a question of 'genealogical justice' (Legendre, 1992). In today's society, this cannot be restricted only to those who are genetically linked, so the notion of genealogical justice must be extended to those who are legally linked as parents and children, irrespective of the genetic link. Through adoption, parental orders and the provisions in the HFE Act, the State recognises socially constructed parenthood which creates legal ties equivalent to those engendered genetically. As an institution, parenthood is at the core of society in providing each individual with a recognised identity, and historically, we see reference in family names to being (the 'son') of someone: Peterson, Von Kassell, de Rothschild and so on. More recently, we see the use of double surnames (or combinations thereof) to reflect the identity of both parents. In the past, natural bonds were provided by the certainty of the genetic link: now with recourse to donated gametes, another mechanism must be adopted to provide equivalent security. Intention has been chosen by the legislator to this end, but as the cases discussed above show, there are flaws in the process which need to be addressed given the importance of the issue.

There are also important communitarian aspects to parenthood as a social institution. Indeed, the common law has always placed importance on a 'secure institution' of parenthood through which individuals find both their voice and identity (Eekelaar 2006). It is imperative to recognise that parenthood creates the family tree which cannot thrive on the basis of what Eekelaar (2006) has termed 'rootless individualism' (at page 174). There are undeniable social consequences of parenthood, reflecting 'the human predicament of interdependence' (Honohan (2002)). The common good must surely include 'family life and the natural bonds of kinship and identity that are at the heart of a well-functioning society' (Laing and Oderberg, 2005). Parenthood is by its nature shared across generations and engenders intergenerational obligations, characterised by some communitarian thinkers as 'life-time 
transcending interests' (Thompson 2009). We inherit identity from our parents (whether genetic or not) and subsequently pass on identity to our offspring. Intention and possible wide ranging models of parenthood following ART mean that the law has to provide an institutionalisation of the individual which can be established with certainty within society and over the years. The purpose of the HFE Act 2008 was to so provide for children born following ART, but it did not take into account either the potentially devastating consequences for children denied legal parents due to procedural error, or the longer term consequences of the weakening of the institution of parenthood, by allowing apparent intention to consent to be denied. The dilution of the certainty of parenthood and its role in society ultimately denies recognition of an individual's identity within an established structure, resulting in her being 'a mere atom floating in a void of social space' (Stone, 1979, p.29). ${ }^{6}$

My argument here is that there is a need to recognise what Lotz (2009) has referred to as a 'procreative morality'. Indeed, for Lotz (2011, p.112): '[A] narrow focus on the interests, values and goods of individual procreators considered solely as individuals, and not at the same time as a member of the moral community, overlooks this crucial aspect of procreative morality'. For my part, there is a parenthood morality in having a coherent structure for recognising a child's parents, both for the resulting children and as a reflection of a partnership between generations. This partnership provides a recognised and recognisable social space in which we interact with others. It also prioritises the child's interests. Yet, administrative errors in the recording of consent have resulted in the wiping away of a child's assumed legal parent, thereby denying her of an element of her identity and familial status. Yet, at the same time, (as the case of Re E and $F$ illustrated), the court has nevertheless underlined the importance of the presence of the non-legal parent in the life of the child. 
Ultimately, the law cannot have it both ways: on the one hand, legislation which fails to consider the long-term interests of children in having legally recognised parents because the procedural consent provisions have not been respected; while on the other hand, courts reinforcing the importance of individuals who play a functional parenting role. The current system remains dominated by consent to treatment (and implicit parenthood that results) based upon an administrative procedure in a clinic, which is not sufficiently robust to ensure both that the parties' intentions are clear, and that the correct recording mechanisms are in place. The uncertainty which can flow therefrom has the potential to be inimical not only to the individual parties concerned, but also to the importance for all of individual and familial identity.

In the light of the complexity of the issue, the need for further consideration of how we establish parenthood is tangible. It is further supported by the incongruence of the vocabulary used: s55A refers to parentage which it is widely accepted should refer specifically to biological links (Bainham 1999). Clearly in the context of ART, we refer to parenthood and it is important that we adopt consistent and logical vocabulary to reflect the reality of the institution to which we are referring. It is time to embark upon a thorough review of the law on parenthood and to move away from the recurring analogy with, or mimicking of, genetic parentage to encompass wider parenthood relationships (Diduck 2007). As McCandless (2012) has noted, '[H]ighly prescriptive legislation, which relies on an arguably outdated family model', does not address current needs. By re-evaluating parenthood, we can recognise the importance for an individual's identity which legal parenthood conveys and look for ways to ensure that a procedure based upon consent is more robust in enshrining intention as the legal mechanism at a fixed point in time (normally just prior to the ART treatment taking place) and for as many families as possible. As numerous cases have shown, 
intention can evolve between the time of conception and the birth and subsequent day-to-day experience of the child's life.

\section{Wider implications?}

Better articulation of intention may also support the potential recognition of more than two parents. For example, the application by the gamete donors and respective partners to have contact with children born to a lesbian couple, who under the 2008 Act were the legal parents of the children in each case suggests that we need to engage, as other jurisdictions have done, with multiple parents: Re G (a minor); Re Z [2013] EWHC 134 (Fam). Whilst it may be thought that in most cases of lesbian parents under the agreed parenthood provision, there is no intention for the sperm donor to play an active role in the child's life, cases which have come before the court show an overall desire by lesbian parents for the child to have some contact with the male progenitor (Millbank 2008), although it is the extent of the contact which often causes the conflict. (See for example, Re D (contact and PR: lesbian mothers and known sperm donor) [2006] EWHC 0002 (Fam); Re B (role of biological father) [2007] EWHC 1952 (Fam)). Clearly, there are important consequences both in material terms and for the child's sense of belonging and identity. Having formal recognition of each parent's role could be beneficial in reducing conflict between the parents and therefore could be in the child's interests (Lotz, 2012; Bracken, 2017). Canada has taken this route, allowing for the registration of three parents on the child's birth certificate, justified by reference to the Charter of Fundamental Freedoms. ${ }^{7}$ Cammu (2018) also notes that a Dutch Government Committee has likewise recommended the establishment of legal parenthood for up to four parents. ${ }^{8}$ In the same way, the influence of the ECHR could be used to allow for such a development in the UK. If we are serious about recognising a variety of family structures, then the law needs to keep pace with regulating the consequences that flow therefrom. Clearer rules on the procedure and ways of enshrining intention as the foundation of legal parenthood 
could address this. Under the ECHR, recourse to the right to family life has enabled a functional approach so that the law can reflect the lived reality of contemporary families. Such an approach not only gives real effect to substantive rights of parents and children alike, but also ensures that the collective interest in having recognisable parameters for attributing parental status is promoted. There is a clear social imperative in legally recognising those who are responsible for children and recognition of a wider pool of parents would seem to be in the interests of all (Young, 1998; Lotz 2012).

Such reform would also contribute to the development of the law relating to birth registration. At present, in the UK, through the process of birth registration, parenthood allows each individual to be registered within a family line of ascendants and descendants. Although historically, this was a record of presumed biological links (Bainham 2008), it is clear that its purpose today is to position each individual as soon as possible after her birth in a legally recognised unit with someone responsible for her. According to a White Paper on Joint Birth registration, '[B]irth registration fulfils the rights of the individual to a home and place in society with the benefits and protection that this brings'.(DWP 2008, para 2.1). A historical record of identity, it also brings with it a number of important legal consequences, and both individuals and society have an interest in how these are regulated. Nevertheless, given that its role has clearly evolved, and that there may be both genetic and social parents to be recognised, reform is to be encouraged. As we have seen, the cases concerning declaration of non-parentage have resulted in a requirement for the child's birth registration to be amended. Consequently, any further reform concerning parenthood should inevitably include consideration of the place and function of birth registration and its content.

\section{Conclusion}


In a case concerning parenthood following treatment using donated gametes under the 1990 Act where the unmarried partners' relationship had broken down, Lord Hope observed:

'There is no doubt that the widening of the frontiers of human existence by the use of assisted reproduction technologies has raised new questions about how the legal relationships that result from their use are to be identified': Re D (A Child Appearing by Her Guardian Ad Litem) [2005] UKHL 33 [5]. Although the reforms adopted in 2008 aimed to make sure that the law was 'fit for purpose' (DoH 2006), this article reveals the shortcomings of the current law with respect to the necessary conditions for recognising legal parenthood.

Notwithstanding the apparent logical development of the parenthood provisions to take into account evolving social constructions of the family and to provide greater regulatory protection for more types of families, it is revealing to observe that very little consideration was given to the consequences of the reform on the institution of parenthood itself. Therefore, there was no opportunity to consider the wider interests which I argue are crucial. Indeed, when the House of Commons Science and Technology Committee put forward arguments for reform of the 1990 Act, it did not mention the need to consider the parenthood provisions at all (House of Commons 2005). The Joint Committee of both houses recommended 'a new approach to parenthood, moving towards the concept of parenthood as a legal responsibility rather than a biological relationship' (House of Lords 2007, para 263) which clearly indicates the lack of in-depth consideration of the issues, given that since the 1990 Act already provided for artificial insemination using donor gametes, legal paternity and maternity were not necessarily dependent upon a genetic relationship anyway. The Committee itself noted that the draft Bill 'gives the impression of tinkering (my emphasis) with existing legislative provisions' giving parenthood as one example of this (para 44). Most importantly, McCandless and Sheldon (2010, at note 28) observe that barely one hour out of 80 hours of 
parliamentary debate on the Bill was spent on the parenthood provisions, and no public consultation has ever been carried out on this question.

Crucially, the lack of focus on the purpose of parenthood, whilst understandable in the early uncharted days of assisted conception centred on infertile heterosexual couples, is now indefensible in an era of diverse family forms. A more child-centric approach which recognises the importance of parenthood for a child's identity and the need for certainty should be reconsidered (Woodhouse, 1993; Shanley, 2001). Although the cases of nonparentage concern parents who are no longer in a relationship with each other, the relationship of each respective parent with the child will typically continue. It therefore seems inescapable that the conclusion to be reached in these cases should be that a declaration of parenthood be made, notwithstanding the administrative errors in the recording of the consent. The child's interests would seem to require this, given that issues such as intestacy, succession, citizenship and financial support stem from legal parenthood. So whilst certainty in the interpretation and strict application of the legislative provisions may be claimed to be behind the decisions in $\operatorname{Re} E \& F$ and $\operatorname{Re} L$ discussed above, there is the question of certainty for the child at the centre of the conflict, and consistency in the treatment of children irrespective of agreement or conflict between the parents.

Furthermore, the cases have underscored the inadequacies and inconsistencies of the dominance of an essentially administrative procedure within the context of clinical practice. It is indeed surprising that the law expects clinics and medical practitioners to undertake such a legally important role. As Ghevaert (2016) asks, 'why are these complex legal aspects of fertility treatment still being put upon nurses and doctors at UK fertility clinics?'.

As I have shown, the 2008 Act is open to challenge, both in terms of the procedural requirements, and potentially unequal treatment between different types of parents, and 
dependent upon the mode of conception. If, as Richards (2006) has noted, assisted reproductive techniques 'produce babies, not parents' (at p71), it is for the law to provide a robust regime for recognising legal parenthood, which is protected as far as possible from the status of the relationship of the parents, and its potential breakdown. Parenthood is, by its very nature, an interdependent relationship, and analogous to Burke's community as a 'partnership not only between the living, but between those who are living, those who are dead and those who are to be born' (Burke 1790). When applying the current legislative provisions on agreed parenthood, and most importantly when considering necessary reform, we should remember that 'the legal determination of parenthood should be first and foremost about the construction of identity,' (Carbone (2005) at p.1334). That must indeed be the point of parenthood and a much clearer articulation of how intention is enshrined as the basis of parenthood would provide greater certainty for an individual's identity.

\section{Disclaimer No conflict of interest}

Orcid: https://orcid.org/0000-0003-1422-5553

\section{Notes}

\footnotetext{
${ }^{1}$ Bainham (2008). According to the author, birth registration provides an accurate report of the birth of the child and identifies the birth parents (although not necessarily the biological parents).

${ }^{2}$ See for example, Re D (a child) [2005] UKHL 33); Re R (IVF: Paternity of Child) [2005] UKHL 33; ARB v IVF Hammersmith Ltd [2017] EWHC 2438 (QB).

3 Administrative errors in the recording of consent to parenthood have been identified in a string of cases including Re HFEA (Cases A, B,C, D, E, F and G) [2015] EWHC 2602 Fam, and In the Matter of the Human Fertilisation and Embryology Act 2008 (Cases AD, AE, AF, AG and AH) (No 2) [2017] EWHC 1782 (Fam).. It is interesting to note that the Department of Health's Post-Legislative Assessment of the HFE Act 2008 states:' Since implementation there have been no significant legal issues or actions with regard to the amended 1990 Act or the parenthood provisions contained in the 2008 Act, as far as the Government is aware.' This is clearly not an accurate description of the situation today. Memorandum to the Health Committee, Cm 8823, March 2014. ${ }^{4}$ Further cases include: Re HFEA (case V) [2016] EWHC 2356 (Fam) and Re HFE Act 2008 (cases P,Q,R,S,T, U)(no.2) [2017] EWHC 2532 (Fam).

${ }^{5}$ I acknowledge of course, that access to ART is possible by a woman on her own, so a child may never have the option of having a second parent. However, that context is different to the one discussed in the above cases, which involves the negation of the legal status of a person (parent) who has been - and may continue to be -
} 
actively involved in the life of the child, and who on the evidence believed themselves to be acquiring parental status.

${ }^{6}$ This analogy is taken from the historical context of blood ties and lineage, where '[i]t was the relation of the individual to his lineage (relatives by blood or marriage, dead, living or yet to be born) which provided a man of the upper classes in a traditional society with his identity, without which he was a mere atom floating in a void of social space.' Lawrence Stone (1979).

${ }^{7}$ See for example, before the Ontario Court of Appeal: $A A v B B$ (2007) ONCA 2; DWH v DJR (2013) ABCA

240; British Columbia, Family Law Act 2013, Part III - Parentage.

${ }^{8}$ The Report is available in Dutch: https://www.rijksoverheid.nl/documenten/rapporten/2016/12/07/rapport-vande-staatsommissie-herijking-ouderschap-kind-en-ouders-in-de-21ste-eeuw.

\section{References}

Bainham, A. (1999) Parentage, Parenthood and Parental Responsibility: Subtle, Elusive Yet Important Distinctions in A.Bainham, S.Day Sclater, M.Richards (eds )What is a Parent? A socio-legal analysis Oxford: Hart pp. 25-46.

Bainham, A. (2008) What is the point of birth registration? 4 CFLQ 449-474.

Brown, A. Two means two, but must does not mean must: an analysis of recent decisions on the conditions for parental orders in surrogacy Child \& Family Law Quarterly 1, 23-40.

Burke, E. (1790) Reflections on the Revolution in France (1790), SMK Books (2012)

Bracken, L. (2017) Challenging normative constructions of parentage in Ireland Journal of Social Welfare and Family Law 39:3 316 -331.

Brannen, J., O’Brian M, (1996) Children in Families: Research and Policy London: Falmer.

Brazier, M, (1999) Regulating the Reproductive Business 7 Medical Law Review 166-193.

Callahan, D. (2003) Individual good and common good: a communitarian approach to bioethics 46 Perspectives in Biology and Medicine 496 -507.

Callus, T. (2012) A new parenthood paradigm for $21^{\text {st }}$ century family law in England \& Wales? 32 Legal Studies 347-368.

Campbell, A. (2007) Conceiving parents through law, International Journal of Law, Policy and the Family 21 (2) 242-273. 
Cammu, N. How Should We Name the Parents? The Challenges of Plus-Two-Parent Families for Legal Kinship Terminology (2018) 31 International Journal of Law, Policy and the Family 328-343.

Carbone, J. (2005) The legal definition of parenthood: uncertainty at the core of family identity 65 Louisiana Law Review 1295-1344.

Department of Health (1984) Report of the Committee of Inquiry into Human Fertilisation \& Embryology, Cmnd 9314.

Department of Health (2006) Review of the Human Fertilisation and Embryology Act Proposals for revised legislation (including establishment of the Regulatory Authority for Tissue and Embryos), Cm 6989 Available at:

http://www.hfea.gov.uk/docs/Review_HFEA_Act_White_Paper_DH.pdf.

Department for Work and Pensions and Department for Children, Schools and Families (2008) Joint Birth Registration: Recording Responsibly, Cm 7293.

Diduck, A. (2007) 'If only we can find the appropriate Terms to use the Issue will be solved: Law, Identity and Parenthood', Child and Family Law Quarterly 19(4), 458-80.

Eekelaar, J (2006) Family Law and Personal Life Oxford University Press.

Epstein, R.A (1992) Justice across the generations in P.Laslett, J.Fishkin (eds) Justice between age groups and generations, Yale University Press, USA.

Ghevaert, L. (2016) Fertility treatment and consent to legal parenthood: no room for errors, Family Law News and Comment, $13^{\text {th }}$ October 2016.

Human Fertilisation \& Embryology Authority (2014a) Fertility Treatment Trends 2014, (HFEA, London).

Human Fertilisation \& Embryology Authority (2014b) Chief Executive Letter, Legal Parenthood CE CE(14) 02 (HFEA, London). 
Human Fertilisation \& Embryology Authority (2016) Chief Executive Letter, Legal Parenthood CE (16) 01, $4^{\text {th }}$ April 2016 (HFEA, London).

Human Fertilisation \& Embryology Authority (2017) State of the Fertility Sector, Report 2016-2017, HFEA, December 2017. Available at:

https://www.hfea.gov.uk/media/2437/hfea_state_of_the_sector_report_tagged.pdf.

Human Fertilisation \& Embryology Authority Code of Practice, chapter 8 on the welfare of the child, paras $8.10-8.11$ : https://www.hfea.gov.uk/code-of-practice/8

Honohan, I (2002) Civic Republicanism London: Routledge.

House of Lords (2007) Human Tissue and Embryos (Draft) Bill, Joint Committee on the Human Tissue and Embryos (Draft) Bill, Session 2006-2007, HL Paper 169-I; HC Paper 630II.

House of Commons (2005) Human Reproductive Technologies and the Law, Fifth Report of the House of Commons Science and Technology Committee (2004-2005) HC 7-I, II. Jackson, E.(2006) What is a parent? In A.Diduck, K.O'Donovan (eds.) Feminist Perspectives on Family Law. Routledge-Cavendish, London pp.59-74.

Laing, J. Oderberg, D.(2005) Assisted Reproduction, The Welfare Principle and Common Good 13 Medical Law Review 328 -356.

Law Commission for England \& Wales (2017) Thirteenth Programme of Law Reform: https://www.lawcom.gov.uk/13th-programme-of-law-reform/ Legendre, P.(1985) L'inestimable objet de la transmission : étude sur le principe généalogique, Paris : Fayard. Legendre, P. (1992) Leçons VI, Les enfants du texte: Etude sur la function parentale des Etats, Paris : Fayard. 
Lotz: M. (2009) Procreative Reason-relevance: On the moral significance of why we have children 23 (5) Bioethics 291-299.

Lotz, M. (2011) Rethinking Procreation: Why it matters why we have children 28(2) Journal of Applies Philosophy 105-121.

Lotz, M. (2012) 'The two-parent Limitation in ART Parentage Law. Old-fashioned law for new-fashioned families' in D. Cutas and S. Chan (eds), Families - Beyond the Nuclear Ideal: Science, Ethics and Society, London/New York: Bloomsbury, pp34-48.

Mackensie, R. (2007) Beyond Genetic and Gestational Dualities: Surrogacy Agreements, Legal Parenthood - Choice in Family Formation in K.Horsey, H.Biggs, Human Fertilisation \& Embryology - Reproducing Regulation, Routledge Biomedical Law and Ethics Library, pp. 233-265.

Masson, J. Harrison, C. (1994) Identity: Mapping the Frontiers, Paper presented at the 8th World Congress of the International Society for Family Law 2 (June 28-July 2, 1994). Masson, J. (2006) Parenting by Being; Parenting by Doing - In Search of Principles for Founding Families in J.R.Spencer, A. du Bois-Pedain Freedom and Responsibility in Reproductive Choice, Oxford: Hart.

McCandless, J Sheldon, S. (2010) The HFE Act 2008 and the Tenacity of the Sexual Family Form Modern Law Review 175-207.

McCandless, J. (2012) The role of sexual partnership in UK family law in D. Cutas and S. Chan (eds), Families - Beyond the Nuclear Ideal:Science, Ethics and Society, London/New York: Bloomsbury pp13-33.

Millbank, J. (2008) The Limits of Functional Family: Lesbian Mother Litigation in the Era of the Eternal Biological Family', International Journal of Law, Policy and the Family, 22(2): 149-77. 
Mulligan, A. Idnetity Rights and Sensitive Ethical Questions: The ECHR and the regulation of surrogacy arrangements Medical Law Review, 26 (3) 449-475.

Shanley, M. (2001) Making babies, making families: what matters most in an age of reproductive technologies, surrogacy, adoption and same-sex and unwed parents, Boston, Beacon Press.

Smith, L. (2013) Tangling the web of legal parenthood: Legal responses to the use of known donors in lesbian parenting arrangements. Legal Studies 33(3), pp. 355-381.

Stone, L. (1979) The Family, Sex, and Marriage in England, 1500-1800 New York: Harper and Row (1977 edition).

Surrogacy UK (2015) Surrogacy in the UK: myth busting and reform, report of the Surrogacy UK working group on surrogacy law reform, November 2015, available here:

https://www.kent.ac.uk/law/research/projects/current/surrogacy/Surrogacy\%20in $\% 20$ the $\% 20$

\section{UK\%20Report\%20FINAL.pdf}

Thompson, J. (2009) Identity and Obligation in a transgenerational polity in A.Goseeries, L.H.Meyer, Intergenerational Justice Oxford University Press, Chapter 1.

Wallbank, J. (2010) Channelling the messiness of diverse family lives: resisting the calls to order and decentring the hetero-normative family 32 Journal of Social Welfare and Family Law 353-368.

Welstead, M. (2016) Biology matters: Part 2: Disputes between lesbian birth mothers and their partners [2016] Fam Law 477.

Woodhouse, B (1993) Hatching the egg: a child-centred perspective on parents' rights Cardoza Law review 14, 1747-1754.

Young, A.H. (1998), “"Reconceiving the "Family"”: Challenging the Paradigm of the Exclusive Family', American University Journal of Gender and Law, 6: 505-555. 
